\title{
GIS DEVELOPMENT FOR GROUND DEFORMATION DATA MANAGEMENT. A CASE STUDY IN CEPHALLONIA ISLAND (WESTERN GREECE)
}

\author{
Vassilopoulou S. ${ }^{1}$, Chousianitis K. ${ }^{1}$, Sakkas V. ${ }^{1}$, Damiata B. ${ }^{2}$, and Lagios E. ${ }^{1}$ \\ ${ }^{1}$ National and Kapodistrian University of Athens, Faculty of Geology and Geoenvironment, \\ Department of Geophysics \& Geothermics, vassilopoulou@geol.uoa.gr,chousia@geol.uoa.gr, \\ vsakkas@geol.uoa.gr.,lagios@geol.uoa.gr \\ ${ }^{2}$ Cotsen Institute of Archaeology, University of California, Los Angeles, CA USA and EarthTech, \\ Inc., Colton, CA USA, damiata@ucla.edu
}

\begin{abstract}
The present study is concerned with the management of multi-thematic geo-data of Cephallonia Island, related to crustal deformation. A large amount of heterogeneous data (vector, raster, ascii files) involving geology, tectonics, topography, geomorphology and DGPS measurements was compiled. Crustal deformation was studied using GPS network consisting of 23 stations. This was installed and measured in October 2001 and re-measured during September 2003 following the Lefkas earthquake of August $2003(M w=6.2)$, and also in July 2006. With proper spatial analysis, a large number of thematic and synthetic layers and maps were produced. Simultaneously, a GIS Data base was organized in order to make an easy extraction of conclusions in specific questions.
\end{abstract}

Key words: data base management, GPS, digital elevation model, terrain analysis maps.

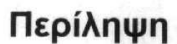

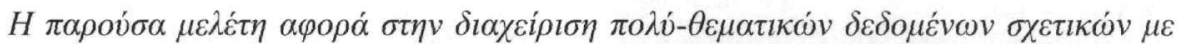

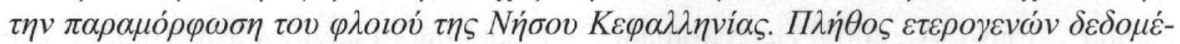

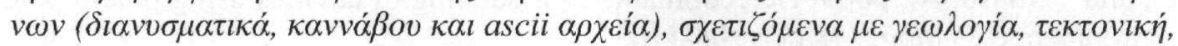

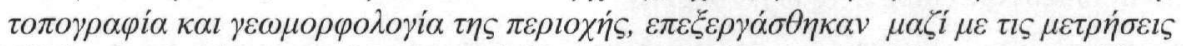

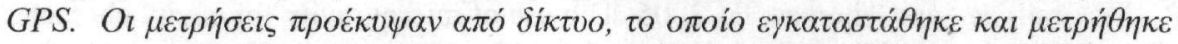

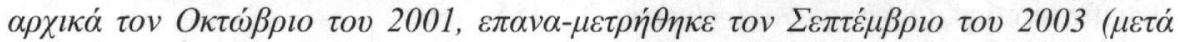

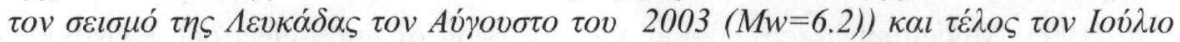

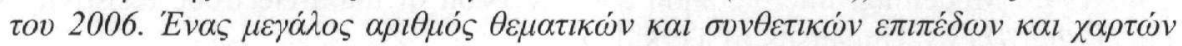

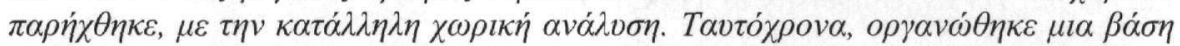

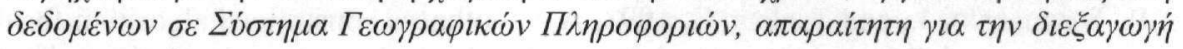
$\sigma v \mu \pi \varepsilon \rho \alpha \sigma \mu \alpha \dot{\tau} \omega \nu$.

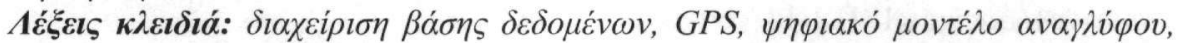
$\chi \alpha \dot{\alpha} \rho \varepsilon \varsigma \alpha v \alpha \dot{\lambda} v \sigma \eta \varsigma \alpha v \alpha \gamma \lambda \dot{\varphi} \varphi o v$. 


\section{Introduction}

Western Greece comprises a seismo-tectonically complex area of rapid and intense deformation. The area of Western Greece became a case history of interaction between the African and the Eurasian lithospheres. The Eastern Mediterranean lithosphere, which is the front part of the African lithosphere, is subducted beneath the Aegean lithosphere, which is the front part of the Eurasian lithosphere, along the Hellenic Arc - Trench System (Le Pichon et al. 1995, Papazachos and Kiratzi 1996, Louvari et al. 1999). This subduction zone terminates against the Cephallonia transform fault, which links this subduction boundary to the continental collision between the Apulia microplate and the Hellenic Foreland (Sachpazi et al. 2000).

The high seismicity level in the region of Cephallonia Island expresses the intense crustal deformation of that region and is strongly associated with right-lateral strike-slip faulting along the Cephallonia transform fault, with earthquake magnitudes up to 7.4 (Louvari et al. 1999). Several strong earthquakes $(\mathrm{M}>6.0)$ have occurred in the Cephallonia area. The last great event $(\mathrm{Mw}=6.7)$ occurred on 17 January 1983, if we do not consider the 14 August 2003 earthquake $(\mathrm{Mw}=6.2)$, involving mostly Lefkada island, northwest of Cephallonia (Papadopoulos et al. 2003, Pavlides et al. 2004). Since then, no other event of comparable magnitude has occurred in the area, although a great number of smaller events $(4.0<\mathrm{Mw}<5.0)$ have been occurred, and at least one event of $\mathrm{Mw} \approx 5.0$ is expected every year.

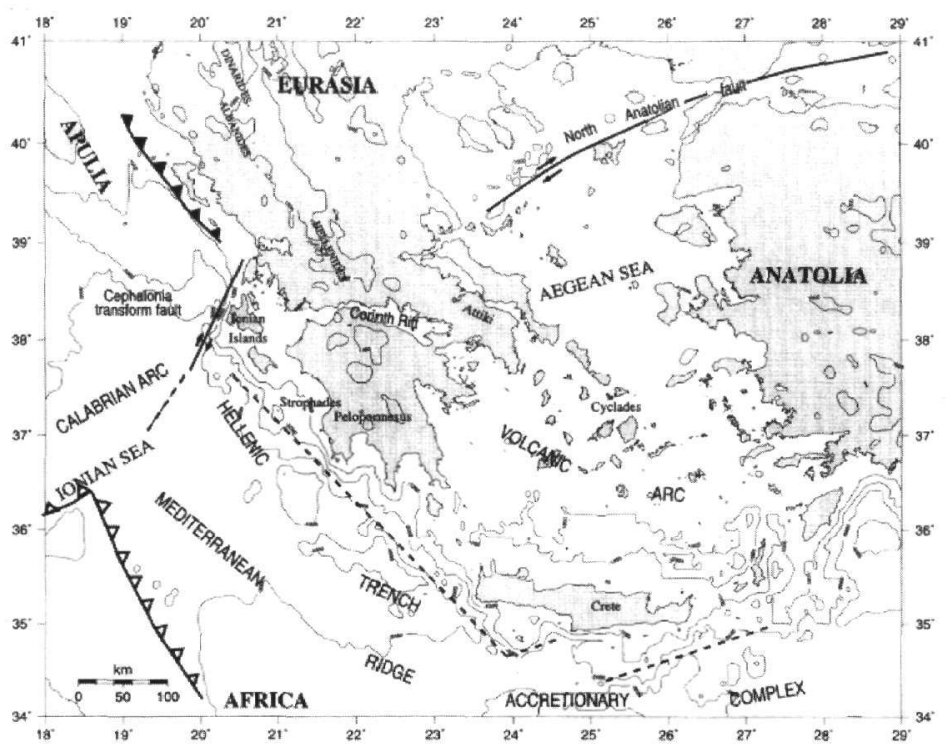

Figure 1 - Sketch map of the Ionian Islands of Western Greece in the Africa-Europe convergence region at the transition zone between Hellenic subduction in the south and continental collision in the north linked by the Cephallonia transform fault (Sachpazi et al. 2000)

Cephallonia is built up mainly by Alpine Mesozoic-Cenozoic sedimentary rocks belonging to the external units of the Hellenides, the Paxos or Pre-Apulian zone and the Ionian zone, which thrusted above (Aubouin and Dercounrt 1962, BP 1971, BP et al. 1985, Lekkas et al. 2001). The Pre-Apulian zone forms the major part of Cephallonia and experienced significant late Neogene and Quaternary shortening (Underhill 1989). The boundary of the Ionian zone is defined by the Ionian thrust, which is generally considered to represent the most external Hellenide structure. The thrust is well exposed in Cephallonia and this boundary is marked by a distinct scarp formed where Mesozoic carbonates of the hanging wall lie next to eroded Miocene marls (BP et al. 1985, Underhill 1989). Compressional tectonics dominates the structure of the Ionian zone. 
Monitoring of dense GPS networks in such an active area may yield useful information regarding the study of local ground deformation and kinematics. At the present study the DGPS data within geological, tectonic and seismological data were processed together and a GIS Data Base was developed for better management and analysis.

\section{DGPS Measurements}

The Differential GPS measurements were taken from 23 GPS stations spread over the island. The 23 stations of the Cephallonia GPS network were installed in October 2001. The locations of the G PS stations were selected according to the main tectonic blocks and faulting zones that could be re cognized in the island, and they were distributed accordingly for the study of the tectonic deformat ion trigerred either by faulting or possible pre- and post- seismic activity. The average spacing of $t$ he stations were $10 \mathrm{~km}$ or less, a distance which is appropriate for a detailed monitoring of local an $\mathrm{d}$ regional tectonic movements. The Cephallonia GPS network was established in October 2001 an d re-measured in September 2003 and July 2006.

Eight dual-frequency geodetic receivers of WILD type (SR299, SR399 \& AX1200Pro) were used for the GPS measurements. The use of Leica's Geoffice Static Kinematic Software allowed the in situ processing and control of the GPS measurements, while the post-analysis of the data was perf ormed using the Bernese GPS Software V. 4.2 (2001). Every campaign was treated separately. Sol utions for every session were calculated by incorporating final IGS satellite orbits in order to impr ove the error estimation of the calculated coordinates of the stations.

For each 24-hour-long session, one site was selected as a "connecting site" in the center of the "roving" receiver sites and was tied to the first-order sites of DION and OBSV. Only the site of DION was kept fixed, since the coordinates and the velocity of this site are known to a high degree of accuracy (ITRF 2000). In the final stage, all sites were tied to the connecting sites on a day-to-day basis. Each roving site was occupied at least twice during each campaign with a minimum recording time of four hours. Selective connecting sites were tied to the main reference sites for periods of at least 48 hours. During our campaigns, the station located on the limestone massif of Aenos Mt. (No 06) was continuously recording throughout the measurement period, and acted as a local reference site. Overall accuracies of 2-3 $\mathrm{mm}$ and $4-6 \mathrm{~mm}$ for the horizontal and vertical components of displacement, respectively, were achieved for all stations.

\section{GIS Development}

Various kind of data (geological, tectonic, topographical, geo-morphological and GPS measurement) in different format (vector, raster, ascii files) and map projections (HATT, UTM etc.), was processed using ArcGIS 8.3 \& 9.1. Thus, a GIS Data base was organized aiming to the creation of a large number of thematic and synthetic layers and maps in a common projection system (Hellenic Geodetic Refference System 1987 - HGRS'87). A data pre-processing step was necessary before the database organization and analysis. This step was divided into the following stages: layer compilation, error correction, conversion of co-ordinates in map projection system, building topology (Vassilopoulou 1999).

\subsection{Data Base Organization}

The compilation of the data base is necessary not only for map creation but it is also a perquisite for the exploitation of GIS capability in order to treat and manipulate data. For this purpose the addition of some items with descriptive information in the attribute table of each coverage was necessary. The data base can constantly be updated with new data, depending on the current needs. The input and output data with their descriptive information are given in the tables 1-4. 
Table 1 - Data Base Schema

\begin{tabular}{|c|c|c|}
\hline \multicolumn{3}{|c|}{ Data Base } \\
\hline Input Data & $\begin{array}{c}\text { Output Thematic \& Synthetic Layers (Cov- } \\
\text { erages \& Grids) }\end{array}$ & $\begin{array}{l}\text { Output } \\
\text { Maps }\end{array}$ \\
\hline $\begin{array}{l}\text { Topography (coastline, con- } \\
\text { tour lines, elevation points, } \\
\text { drainage network, from } \\
\text { 1:50000 scale maps of the } \\
\text { Hellenic Millitary Geo- } \\
\text { graphical Service (1976) }\end{array}$ & $\begin{array}{l}\text { coast (arcs) } \\
\text { contours (arcs) } \\
\text { elevpnt (points) } \\
\text { river (arcs) }\end{array}$ & $\begin{array}{l}\text { Dem } \\
\text { Shaded Re- } \\
\text { lief }\end{array}$ \\
\hline $\begin{array}{l}\text { Morphology (morphological } \\
\text { layers) }\end{array}$ & $\begin{array}{l}\text { boundary (the outer boundary of the interpo- } \\
\text { lated DEM /an area encompassing } 200 \mathrm{~m} \text { ma- } \\
\text { rine area around the island) } \\
\text { dem } 20 \text { (DEM) } \\
\text { slope (morphological slopes } \% \text { - polygons) } \\
\text { aspect, aspnt (aspect of morphological slopes } \\
\text { - polygons and point respectively) } \\
\text { discontinuity (discontinuities of morphologi- } \\
\text { cal slopes - arcs) }\end{array}$ & $\begin{array}{l}\text { Map of } \\
\text { Terrain } \\
\text { Analysis }\end{array}$ \\
\hline $\begin{array}{l}\text { Geology (geological forma- } \\
\text { tions) }\end{array}$ & $\begin{array}{l}\text { geology (polygons) } \\
\text { geolslp, geolslv, geolslve, geolslvf (polygons) } \\
\text { (combination of "geology", "slope", "v0306" } \\
\text { and "tectbuf") }\end{array}$ & $\begin{array}{l}\text { Geological } \\
\text { Map }\end{array}$ \\
\hline $\begin{array}{l}\text { Tectonic (thrusts, over- } \\
\text { thrusts, faults) } \\
\text { Fault Blocks }\end{array}$ & $\begin{array}{l}\text { tectonic (arcs) } \\
\text { tectbuf (polygon-buffer zone of tectonic) } \\
\text { faultblock (polygons) }\end{array}$ & $\begin{array}{l}\text { Tectonic } \\
\text { Map }\end{array}$ \\
\hline $\begin{array}{l}\text { GPS measurements } \\
\text { (Sept2001-Sept2003, } \\
\text { Sept2003-Jul2006, } \\
\text { Sept2001-Jul2006) } \\
\text { GPS station for each period } \\
\text { Horizontal Displacement } \\
\text { from GPS receivers illus- } \\
\text { trated as an arrow } \\
\text { Vertical Displacement from } \\
\text { GPS receivers } \\
\text { Error of Horizontal Dis- } \\
\text { placement illustrated as a } \\
\text { circle }\end{array}$ & $\begin{array}{l}\text { gpsp01, gps03sscale, gps06jscale (points) } \\
\text { gps0103s, gps03s06j, gps01s06j (arcs) } \\
\text { Z0103s, Z03s06j, Z01s06j (grids) } \\
\text { v0306 (vertical deformation in polygon cover- } \\
\text { age) } \\
\text { stddifscale0103s, stddifscale03s06j stddif- } \\
\text { scale01s06j (polygon - buffer zone) } \\
\text { "question" the coverage-answer in specific } \\
\text { question }\end{array}$ & $\begin{array}{l}\text { Maps of } \\
\text { Horizontal } \\
\text { \& Vertical } \\
\text { Deforma- } \\
\text { tion }\end{array}$ \\
\hline $\begin{array}{l}\text { Seismology (earthquake epi- } \\
\text { centres) }\end{array}$ & epicenter (points) & $\begin{array}{l}\text { Seismologi- } \\
\text { cal Map }\end{array}$ \\
\hline
\end{tabular}


Table 2 - Descriptive Information of Thematic and Synthetic Layers related to Tectonic, Geology and Seismology

\begin{tabular}{|c|c|c|}
\hline $\begin{array}{c}\text { Tec- } \\
\text { tonic/Geolo } \\
\text { gy/Seismolo } \\
\text { gy and Syn- } \\
\text { thetic Lay- } \\
\text { ers }\end{array}$ & Items & Description \\
\hline \multirow[t]{6}{*}{ tectonic } & code & Unique number for each data \\
\hline & name & The name of each fault or faulting zone \\
\hline & zone & The name of each faulting zone in abbreviation \\
\hline & activity & Characterization of each fault as active or possible active \\
\hline & order & Classification of each fault as main or secondary \\
\hline & visible & Characterization of each fault as visible or invisible \\
\hline faultblock & $\begin{array}{l}\text { name } \\
\text { code }\end{array}$ & Each fault block is characterized by its name and its number \\
\hline geology & formation & Classification of geological formation \\
\hline coast & elevation & elevation \\
\hline contours & elevation & elevation \\
\hline elevpnt & elevation & elevation \\
\hline \multirow{8}{*}{$\begin{array}{l}\text { epicenter } \\
\text { (earthquake } \\
\text { epicenters of } \\
\text { August- } \\
\text { October } \\
2003 \text { ) }\end{array}$} & Year & the year of the earthquake \\
\hline & Date & the date of the earthquake \\
\hline & hr_min_sec & the time of the earthquake \\
\hline & long_e, lat_n & the coordinates of the earthquake \\
\hline & $\mathrm{H}$ & the depth of the earthquake \\
\hline & M & the magnitude of the earthquake \\
\hline & Codem & the epicenters are categorized related to $\mathrm{M}$ \\
\hline & Codemh & the epicenters are categorized related to $\mathrm{M}$ and $\mathrm{H}$ \\
\hline
\end{tabular}


Table 3 - Descriptive Information of GPS Layers

\begin{tabular}{|l|l|}
\hline $\begin{array}{l}\text { Specific Items of GPS } \\
\text { Layers }\end{array}$ & Description \\
\hline $\begin{array}{l}\text { "easting_a", "nor- } \\
\text { thing_a", "easting_b", } \\
\text { "northing_b" }\end{array}$ & $\begin{array}{l}\text { Coordinates of GPS stations for each period (a: begin of vector/first } \\
\text { measurement, b: end of vector/last measurement) }\end{array}$ \\
\hline "ellip_h_a", "ellip_h_b" & Z coordinate of GPS station \\
\hline $\begin{array}{l}\text { "stdeast_a", } \\
\text { "sd_east_b" }\end{array}$ & Standard deviation along easting coordinate \\
\hline $\begin{array}{l}\text { "sd_north_a", } \\
\text { "sd_north_b" }\end{array}$ & Standard deviation along northing coordinate \\
\hline "sd_h_a", "sd_h_b" & Standard deviation along height \\
\hline "azimuth" & Horizontal displacement direction \\
\hline "elldif_mm", "hightdif" & Horizontal and vertical deformation in mm \\
\hline "stdevdifn" "stdevdife" & Standard deviation of horizontal displacement along X and Y axis \\
\hline "stdevh_mm" & Standard deviation of horizontal displacement along Z axis \\
\hline "xscale", "yscale" & $\begin{array}{l}\text { "phseudo-coordinates" of the end of horizontal displacement arrow } \\
\text { (they produced after real coordinates scaling for its representation } \\
\text { on the map) }\end{array}$ \\
\hline "value" & $\begin{array}{l}\text { "phseudo-error" of horizontal displacement along X axis for its } \\
\text { representation on the map (the error after scaling) }\end{array}$ \\
\hline vertical displacement \\
\hline
\end{tabular}

Table 4 - Descriptive Information of Morphological Layers

\begin{tabular}{|l|l|l|}
\hline $\begin{array}{c}\text { Morphological } \\
\text { Layers }\end{array}$ & \multicolumn{1}{|c|}{$\begin{array}{c}\text { Specific } \\
\text { Items }\end{array}$} & \multicolumn{1}{c|}{ Description } \\
\hline dem20 & value & elevation \\
\hline slope & $\begin{array}{l}\text { percent } \\
\text { slope }\end{array}$ & Classification of morphological slopes in categories \\
\cline { 2 - 3 } & slope-code & Unique number for each category of morphological slope \\
\cline { 2 - 4 } & code2 & $\begin{array}{l}\text { Unique number for specific categories of morphological } \\
\text { slopes }\end{array}$ \\
\hline \multirow{2}{*}{ aspect } & aspect & $\begin{array}{l}\text { Categories of angles for the calculation of the aspect of } \\
\text { slopes }\end{array}$ \\
\cline { 2 - 4 } & aspect-code & Unique number for each category of aspect \\
\hline \multirow{3}{*}{ discontinuity } & $\begin{array}{l}\text { lcode, } \\
\text { rcode }\end{array}$ & $\begin{array}{l}\text { Codes related to the right and left polygons that discontinuity } \\
\text { is boundary }\end{array}$ \\
\cline { 2 - 4 } & $\begin{array}{l}\text { lmedh, } \\
\text { rmedh }\end{array}$ & The height of the right and left polygons \\
\cline { 2 - 4 } & newID & New ID of each discontinuity \\
\cline { 2 - 4 } & code & Unique number for each discontinuity \\
\hline range & code & Unique number for each category of elevation zones \\
\hline
\end{tabular}




\subsection{Map Creation}

\subsubsection{Generation of Digital Elevation Model}

Interesting results can be extracted concerning tectonics, morpho-tectonics, geodynamics, geophysics etc. of an area, from a close study of terrain. The digital elevation model (DEM) is the main feature for the terrain analysis of a region: a) It represents a modern digital topographic map in 3-D and serves as a base for thematic applications (in the laboratory and field work) like geology, volcanology, geophysics, geochemistry, ortho-rectified satellite images, interferometry, etc. b) It also serves as a base for compilation of a great variety of maps relating to the terrain analysis (3-D maps, slope-aspect maps, maps of planation surfaces, maps of discontinuities of morphological slopes etc.).

The applied methodology for obtaining a DEM depends on numerous parameters, like the type of the data (contours, points, drainage network, etc), the quality and the density of the data, relating to the morphology of the study area, as well as the use of the DEM. The result (DEM) depends on the parameters of the applied algorithm, the dimension of the DEM (i.e the pixel size of the regular grid to be interpolated), the scale of the map in which the DEM is represented, etc. (Vassilopoulou 1999, Vassilopoulou 2001, Vassilopoulou and Hurni 2001, Vassilopoulou et al. 2002). The basic input data for the production of the DEM were contours with a good density $(20 \mathrm{~m}$ contour interval, as well as $10 \mathrm{~m}$ in some specific regions), together with elevation points and drainage network, from 1:50000 scale paper maps. Having then this kind of data available, the TOPOGRID algorithm of ArcGIS version 8.3 was able to generate the proper grid of elevation (ESRI 1997, Vassilopoulou 1999, ESRI 2001). A 20m-resolution DEM of Cephallonia Island was finally produced, in grid format.

\subsubsection{Maps of Ground Displacements}

Ground deformation maps were created after combination of vertical and horizontal deformation layers (Table 1). Data base organization with descriptive information in specific items is capable of helping the representation of the data (Table 3).

Horizontal deformation (in vector format), from GPS receivers, illustrated as arrows which indicate the direction of the displacement. The error of horizontal displacement illustrated as circles at the end of each arrow.

Vertical displacement (in grid format) from GPS receivers, illustrated as a colour scale from blue (small deformation) to red (high deformation). At the Figures 2-4 the ground deformation of Cephallonia during 2001-2006 can be observed. The ground deformation is overlaid on the shaded relief of the island for more realistic representation. The layer of tectonic zones as well as other geological data can be combined with GPS data to produce synthetic maps and make the results extraction easier.

\subsubsection{Maps for Terrain Analysis}

Terrain analysis of a region is the base feature for each geo-environmental study (management of geo-environmental problems-natural hazards, large public constructions, waste-disposal areas, land use, studies regarding geodynamics, hydrogeology, geophysics etc.). At the present study the "Shaded Relief", "Slope - Aspect Map", "Range Map" and "Map of Morphological Discontinuities of Slopes" were produced based on the above DEM by the use of specific software "PROANA" (Vassilopoulou, 1999, Vassilopoulou, 2001). Their data base has been updated with useful information (Table 4). These maps can be used for specific question solution (section 4).

\section{Shaded Relief}

Shaded relief as well as 3-D models were useful for our work. Draping thematic maps (geological, tectonic, ground deformation etc.) over the DEM, were produced more realistic images (Figs 2-4). 
These images were important for field work (position of DGPS measurements identification) as well as in the laboratory together with other data.

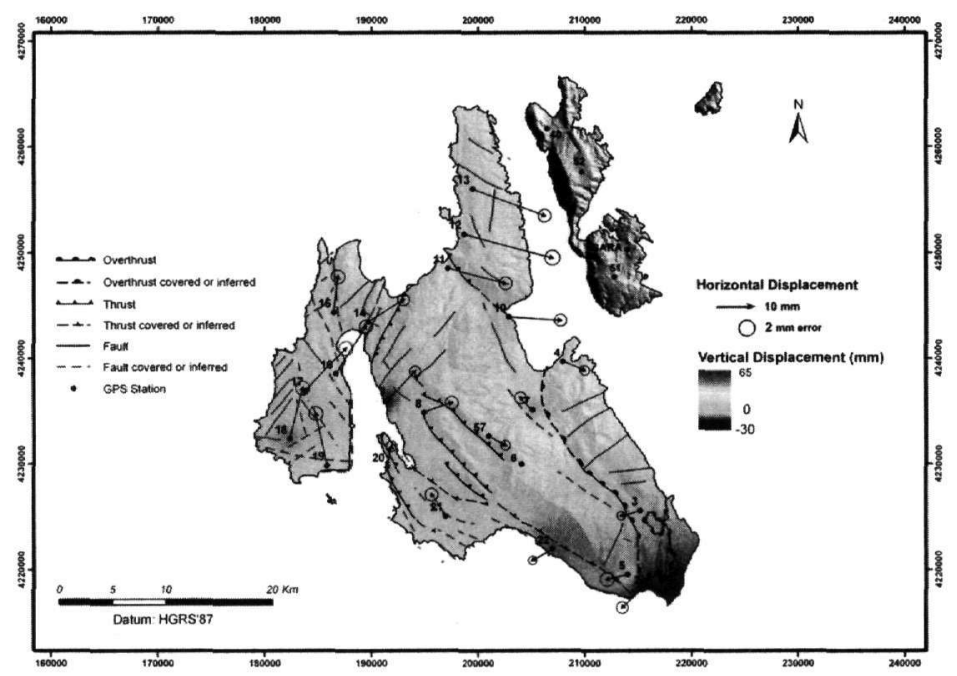

Figure 2 - The ground deformation of Cephallonia (Oct. 2001-Sept. 2003) is given. Horizontal displacements that occurred had magnitudes less than $20 \mathrm{~mm}$ for the majority of stations and a clockwise rotation relative to Aenos mountain can be observed. Subsidence occurred along the southern and SE parts (e.g., Skala area). Small uplift of about $10 \mathrm{~mm}$ occurred at the northern and western parts of the island, while more intense uplift $(>15 \mathrm{~mm})$ appeared in the eastern part

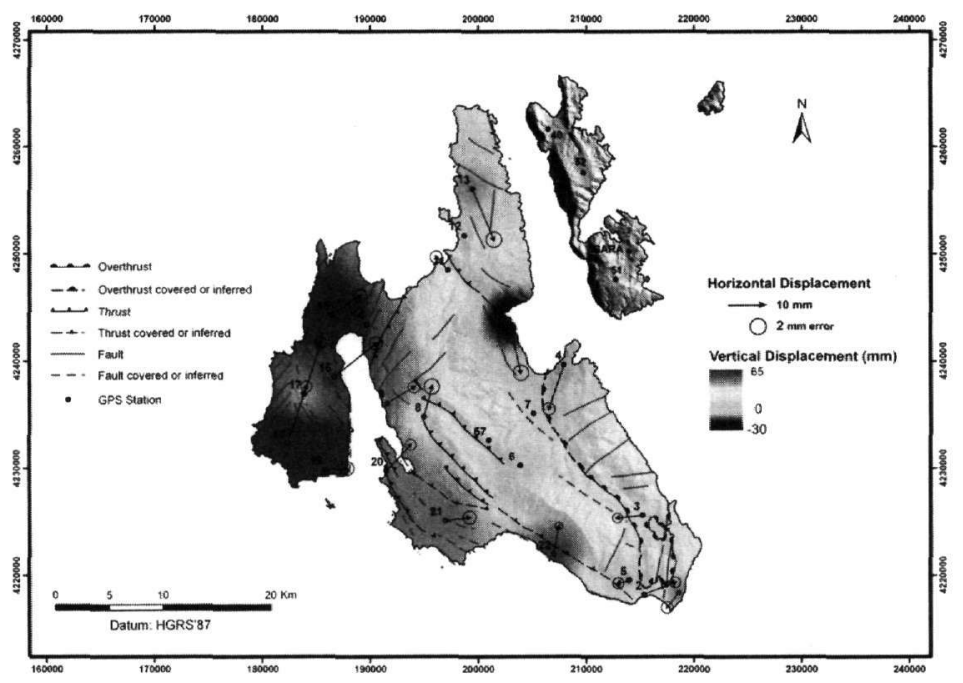

Figure 3 - The ground deformation of Cephallonia (Sept. 2003-July 2006) is represented. The horizontal pattern at the western and northern part of the island does not significantly change compared to the first period. At the southern part small changes occur at some stations especially located at the multi-fragmented micro-tectonic blocks (SE part). In the vertical component of deformation, the western and southern parts have been strongly uplifted, while the rest of the island maintained a similar behavior as the previous observational period 


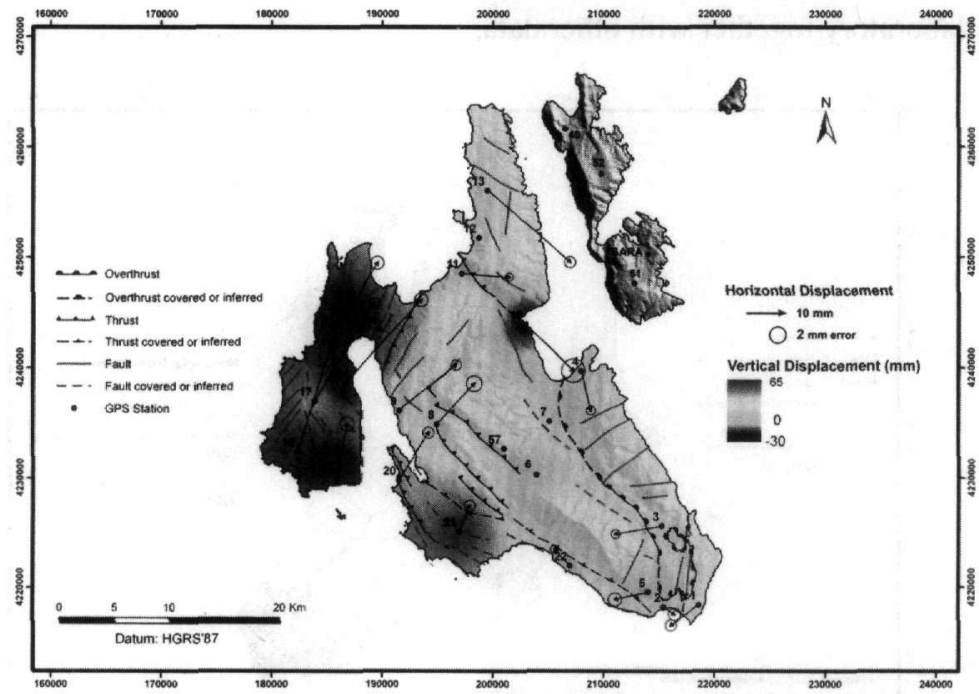

Figure 4 - The ground deformation of Cephallonia (Oct. 2001-July 2006) is observed. The horizontal deformation confirms the clockwise rotation that appeared in the first two periods of observations. A very strong uplift at the western and southern parts of the island can be observed, whereas subsidence occurred along the SE parts and around the station 10 at the east-northeast. Uplift with smaller magnitudes is observed at the rest of the island

\section{Slope - Aspect Map}

The "Slope - Aspect Map" or "Map of Morphological Slopes" represents the slopes of the terrain classified in regions, as well as the aspect of the slopes (Fig. 5b). This map was compiled of slope and aspect layers after further processing (The database of each layer was updated with useful descriptive information while the un-useful information was removed).

The slopes at the region of Cephallonia Island were classified in categories: $0-5 \%, 5-15 \%, 15-$ $30 \%, 30-45 \%, 45-60 \%$, slopes $>60 \%$. They represented in a color scale from light yellow (small slopes) to dark brown (high slopes). The angles of aspect were categorized by $45^{\circ}$ and were transformed in to Arc/Info format. They illustrated as arrows

\section{Range Map}

The study area was divided in categories of 20 meters elevation zones. These zones were contained in the range-polygon layer. The range-layer is useful for morphological discontinuities creation.

\section{Map of Morphological Discontinuities of Slopes}

The "Map of Morphological Discontinuities of Slopes" is represented the differences in slope more than $10 \%$. The morphological discontinuities are boundaries of polygons with specific characteristics in the layer of the slopes. This layer is a compilation of thematic layers of aspect, slope and range. Further processing conduct to the final thematic layer of the morphological discontinuities. The arcs-morphological discontinuities are then taking the proper shape to be subsequently represented by the analogous symbol. So that, the "Map of Morphological Discontinuities of Slopes" was produced. Morphological Discontinuities were including in the data base, for synthetic map creation related to our study (Fig. 5b). 


\subsubsection{Geological and Tectonic Map}

Geological and tectonic data were included in the GIS data base (Tables 1, 2). Geological and tectonic layers as well as maps were produced. These layers were also used for synthetic maps creation (Fig. 5a) and data base analysis.

\section{GIS Data Base Analysis}

After the data base was updated with sufficient amount of data, its analysis and management can provide solutions to certain target-oriented queries. During 2003-2006, intense horizontal and vertical deformation was observed in some regions of the Cephallonia Island. The data base organization allows us to take answers in particular questions like: a) In which area the stronger deformation is observed? or b) Where the ground deformation is low? or c) Which area is suitable for building? etc.

Parameters specification:

At first, we set the parameters related to our study. In the question "Which area is suitable for building", the parameters could be: a) Limestones (stable formations), b) Gentle Slopes, c) $-20 \mathrm{~mm}$ $<$ Vertical Deformation $<20 \mathrm{~mm}$, d) $1 \mathrm{~km}$ distance around the faults.

Continuously, the data base analysis was as follows:

- All the layers had to be in the same format (i.e. vector). Thus, the layer of the vertical deformation (in grid format) "Z03s06j" is converted to the polygon coverage "v0306"

- The thematic layers of geology, slope and vertical deformation were combined (using "identity", "eliminate" etc.) into one coverage: "geology" + "slope" + "v0306" = "geolslv"

- A coverage-buffer zone ( $1 \mathrm{~km}$ distance around tectonic zones) was created: "tectbuf"

After further processing, the geological formations, tectonic zones, morphological slopes and vertical deformation were grouped into specific items and the desired areas were extracted in the "question" coverage (Figs 5a, b, c).

\section{Conclusion}

A large amount of heterogeneous data (vector, raster, ascii files), were compiled and a GIS Data Base was organized in order to accomplish the following aspects:

- The Database management, analysis and update with the useful information.

- The compilation of the information and the production of thematic and synthetic layers and maps related to the ground deformation using differential GPS measurements, geology, tectonics, seismology, topography (DEMs), geomorphology (slope and aspect maps, maps of morphological discontinuities) etc., in a common projection system.

- Facilitation of conclusion extraction.

The GIS Data Base can be constantly updated and improved as well as a decision making system can be created in the future in order to solve particular problems related to our study. 


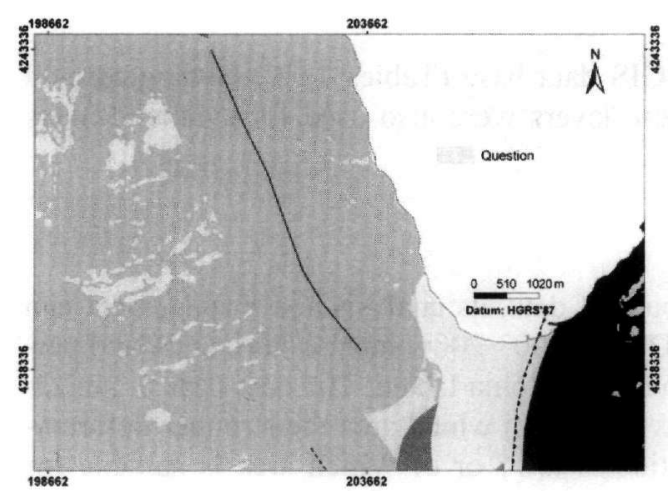

(a)

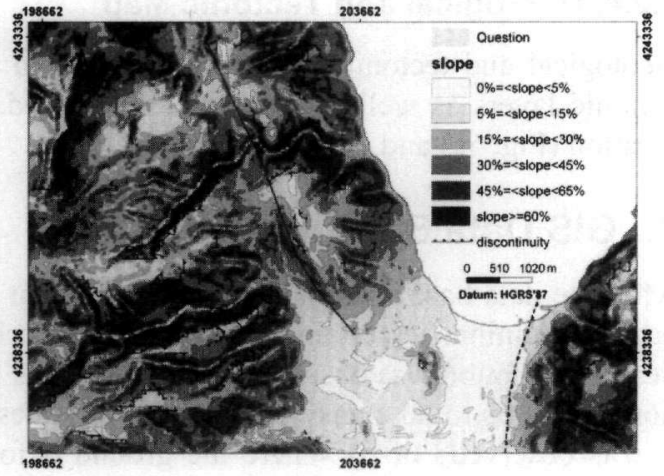

(b)

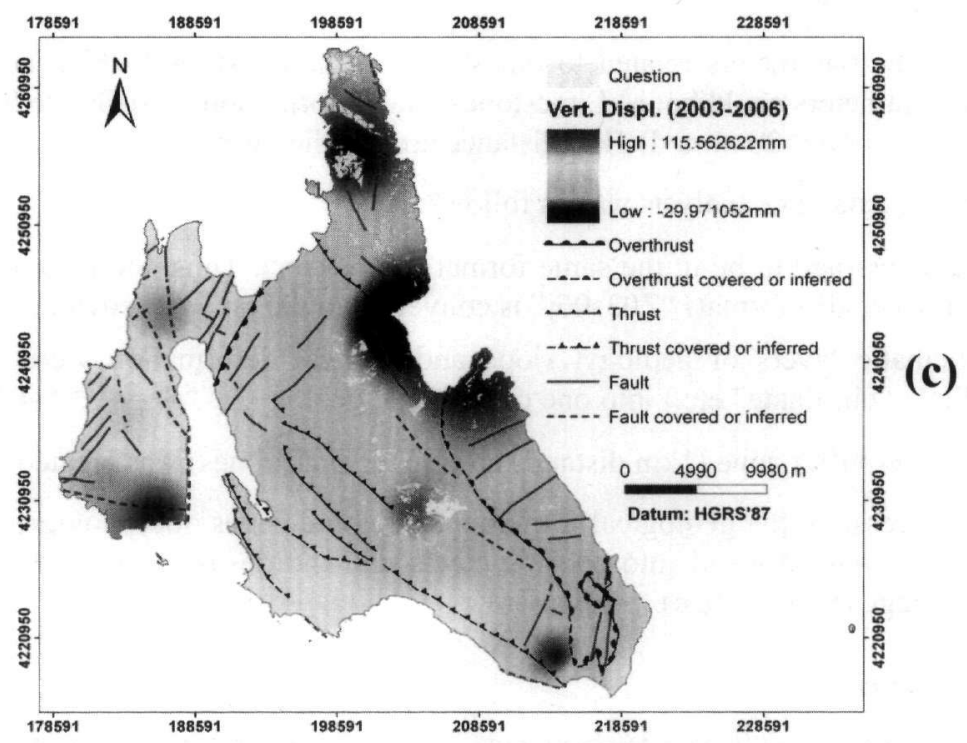

Figure 5 - The answer areas (gray colour) as they extracted after data base analysis related to the question "which area is suitable for building". The areas fulfill the conditions of the

question: They lay on limestones (a), with gentle slopes from $0 \%$ to $15 \%$ (b), at $1 \mathrm{~km}$ distance from the faulting zones and the vertical deformation is between of $-20 \mathbf{~ m m}$ to $20 \mathrm{~mm}$ (c)

\section{References}

Aubouin, J., and Dercourt, J., 1962. Zone Preapoulien, Zone Ionienne et Zone de Gravrovo en Pelloponnese occidentale, Bull. Soc. Geol. France, 4, 785-794.

Bernese GPS Software, 2001. Version 4.2, Astronomical Institute, University of Bern, U. Hugentobler, S. Schaer and P. Fridez (eds), 515pp.

British Petroleum Co., 1971. The geological results of petroleum exploration in Western Greece, Spec. Stud. Geology of Greece, No10, Printed by the Institute of Geology and Mineral Exploration (IGME), Greece.

British Petroleum Co., University of Munich and Migiros, G., 1985. Geological map of Greece, Sheet "Kefallonia (Northern and Southern part)", printed by the Institute of Geology and Mineral Exploration (IGME), Greece. 
ESRI, 1997. Using ARC GRID with ARC/INFO, ESRI, Redlands, CA.

ESRI, 2001. ArcDOC for Arc/Info Workstation, version 8.

Le Pichon, X., Chamot-Rooke, N., Lallemant, S., Noomen, R., and Veis, G., 1995. Geodetic determination of the kinematics of Central Greece with respect to Europe: implications for Eastern Mediterranean tectonics, J. Geophys. Res., 100, 12 675-12 690.

Lekkas, E., Danamos, G., and Maurikas, G., 2001. Geological structure and evolution of Kefallonia and Ithaki Islands, Bull. Soc. Geol. Greece, XXXIV/1, 11-17.

Louvari, E., Kiratzi, A., and Papazachos, B.B., 1999. The Cephalonia Transform Fault and it's extension to Western Lefkada Island (Greece), Tectonophysics, 308, 223-236.

Papadopoulos, G., Karastathis, V., Ganas, A., Pavlides, S., Fokaefs, A., and Orfanogiannaki, K., 2003. The Lefkada, Ionian Sea (Greece), shock (Mw 6.2) of 14 August 2003: Evidence for the characteristic earthquake from seismicity and ground failures, Earth Planets Space, 55, $713-718$.

Papazachos, C., and Kiratzi, A., 1996. A detailed study of the active crustal deformation in the Aegean and surrounding area, Tectonophysics, 253, $129-153$.

Pavlides, S., Papadopoulos G., Ganas A., Papathanassiou G., Karastathis V., Keramydas D., and Fokaefs, A., 2004. The 14 August 2003 Lefkada (Ionian Sea) earthquake, $5^{\text {th }}$ International Symposium on Eastern Mediterranean Geology, Thessaloniki, Greece, 14-20 April 2004.

Sachpazi, M., Hirn, A., Clement, C., Haslinger, F., Laigle, M., Kissling, E., Charvis, P., Hello, Y., Lepine, J.-C., Sapin, M., and Ansorge, J., 2000. Western Hellenic subduction and Cephalonia Transform: local earthquakes and plate transport and strain, Tectonophysics, 319, 301-319.

Underhill, J.R., 1989. Late Cenozoic deformation of the Hellenic foreland, Western Greece, Bulletin of Geological Society of America, 101, 613-634.

Vassilopoulou, S., 1999. Geodynamics of the Argolis Peninsula with GIS development and the useof Remote Sensing Data. PhD Thesis, University of Athens, Faculty of Geology, 194pp.

Vassilopoulou, S., 2001. “PROANA”A useful software for terrain analysis and geoenvironmentalapplications - study case on the geodynamic evolution of Argolis Peninsula, Greece, Proc. 20th International Cartographic Conference, Beijing, China. Chinese Society of Geodesy, Photogrammetry and Cartography, 3432-3440pp.

Vassilopoulou, S., and Hurni, L., 2001. The use of digital elevation models in emergency and socio- economic planning: a case study at Kos-Yali - Nisyros-Tilos Islands, Greece, Proc. 20th International Cartographic Conference, Beijing, China. Chinese Society of Geodesy, Photogrammetry and Cartography, pp. 3424-3431.

Vassilopoulou, S., Hurni, L., Dietrich, V., Baltsavias, M., Pateraki, M., Lagios, E., and Parcharidis, Is., 2002. Ortho-Photo Generation using IKONOS-2 Imagery and High Resolution DEM: A Case Study on Volcanic Hazard Monitoring of Nisyros Island (Greece), ISPRS Journal of Photogrammetry and Remote Sensing, 57, 24-38. 